IJAMSR 2 (2) www.ijamsr.com CrossRef: https://doi.org/10.31426/ijamsr.2019.2.2.1213

\title{
FEASIBILITY OF 2D FINE ART LEARNING MEDIA USING I-SPRING TECHNOLOGY FOR CLASS X SMA BATIK 2 SURAKARTA
}

\author{
Misron Zen Fatro ${ }^{1}$, Edy Tri Sulistyo ${ }^{2}$, Sugeng Nugroho ${ }^{3}$ \\ ${ }^{1}$ Student of Art Education, Postgraduate School,Sebelas Maret University, Surakarta, \\ Indonesia, \\ ${ }^{2,3}$ Lectures of Art Education Study Program Sebelas Maret University, Surakarta, \\ Indonesia,
} misron_zen@yahoo.co.id

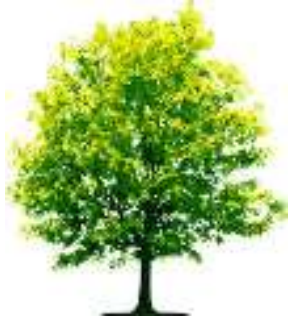

Keywords: Learning Media, ISpring, Two-Dimensional Art

\begin{abstract}
A B S T R A C T
The development of learning media in fine art material very much needed at this time. This study aims to determine the characteristics and feasibility of I-Spring technology learning media in two-dimensional art material. I-Spring is a computer-based application that can package learning materials with interactive multimedia and has evaluation tools that attract students' attention. The method of research used is research and development with research subjects as much as 26 (twenty-six) students of class $X$ SMA Batik 2 Surakarta. Development of I-Spring technology learning media must include stages; (1) preliminary research, (2) development, design, (3) production, (4) product validation Then the product validation stage, the stage where the product in the form of two-dimensional art learning media produced, tested for feasibility through several stages, namely; (1) expert test, (2) revision I, (3) small group trial, (4) revision II, (5) large group trial, (6) revision III. The results showed that media feasibility was measured through product validation by media experts, material experts, and students with completeness criteria of $64 \%$ in the good category. The material expert test results were $89 \%$ very good criteria, and the media expert test was $93 \%$ very good criteria, provided that they had to go through the revision stage I, then the small group test results were $88 \%$ very good criteria to revise II requirements, and large group test results $90 \%$ very good category with revision III requirements. Based on the results of product validation, it can conclude that I-Spring technology learning media in twodimensional art material for class $X$ high school declared feasible to be mass produced and applied in the classroom.
\end{abstract}

Citation: Misron Zen Fatro, Edy Tri Sulistyo, Sugeng Nugroho (2019). Feasibility Of $2 D$ Fine Art Learning Media Using I-Spring Technology For Class X SMA Batik 2 Surakarta. International Journal of Advanced Multidisciplinary Scientific Research (IJAMSR ) ISSN:2581-4281, 2 (2), February, 2019, \# Art.1213, pp 29-40 


\section{International Journal of Advanced Multidisciplinary Scientific Research (IJAMSR) ISSN:2581-4281}

\section{Introduction}

An alternative media development that is suitable to improve student learning achievement in learning Two-Dimensional Art material includes developing technology-based learning media such as I-Spring. The I-Spring program works to make PowerPoint files more interesting and interactive based on Flash and can open on all computers. The making of computer technology-based learning media, especially using Flash applications, is the favorite choice of teachers, using Flash makes it possible to present interesting learning material and be presented interactively (Muh Taminudin, 2014: 1-2). One of the most fundamental advantages of the I-Spring program is the interactive quiz, where there are several types of quizzes in it (Kuswari Hernawati, 2010: 1). True / False, Multiple Choice, Multiple responses, Type In, Matching, Sequence, Numeric, Fill in the Blank, Multiple Choice Text, Hot Spot, is a type of excellent quiz program offered by ISpring.

The I-Spring program can provide examples of clear and tangible works on two-dimensional art material, both from the presentation of presentations of material, videos, digital books, or interactive quizzes. These strengths strongly support the learning of two-dimensional art in the classroom, because the teacher can present examples of works, elements, principles, tools, materials, media, and techniques in twodimensional art clearly and attractively without having to present it directly. The I-Spring quiz also greatly helps students' understanding of two-dimensional art material, for example of the type of Multiple choices on I-Spring able to present real images for students to be able to understand the problem well, where the conditions are difficult to apply on the Paper test (test with paper).

Observations made through classroom document observation and interviews with students, especially regarding Cultural Arts lessons in the X-grade Two-Dimensional Art material at Surakarta Batik 2 High School during the 2017/208 school year show that the achievement of quality learning in Cultural Arts subjects in the two-dimensional fine art material less optimal. These shortcomings can see through student learning outcomes in the form of cognitive competency test scores of two-dimensional art material derived from the cognitive pretest grade X IPA 1 Surakarta Batik 2 grade TA.2017 / 2018, in table 1 below: 


\section{International Journal of Advanced Multidisciplinary Scientific Research (IJAMSR) ISSN:2581-4281}

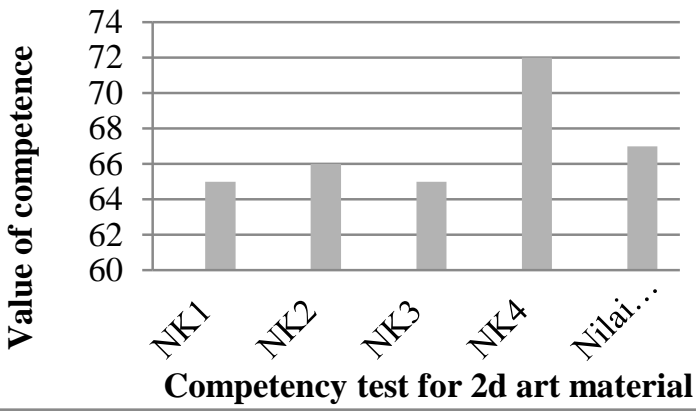

Source: Cognitive Pretest

Graph 1. List of cognitive pretest values of class X IPA students 1 SMA Batik 2 Surakarta academic year 2017/2018 Cultural Arts subject matter Two Dimensional Art.

Information:

NK1: The submersion competency value is the understanding of two-dimensional art

NK2: The competency value of the submersion of elements and principles of two-dimensional art

NK3: Competency value for submersion of two-dimensional art tools, materials \& media

NK4: The competency value of the submission technique works in twodimensional art

The minimum completeness criterion (KKM) value is 75 (seventy-five)

Based on the problems described above, it is necessary to develop learning media that can help limit the teacher's ability and the limitations of the learning module in two- dimensional art material. I-Spring Media is a computer-based media that is interactive, interesting, and fun for students, so it can improve the quality of learning in twodimensional art material, both in terms of processes and learning outcomes. Azhar Arsyad (2011: 35-36) states that computerbased learning media are learning media that make and deliver learning material using computer microprocessors where the material has designed and programmed into a storage device, such as; CD and flash disk. The study aimed to find out the procedure for developing I-Spring technology learning media in twodimensional art material in high school.

\section{Method}

This research conducted in the 2017/2018 school year, which is mid-odd semester in December 2017 until July 2018. The object of the research and sample of the study are the tenth-grade students of SMA Batik 2 Surakarta in the academic year 2017/2018. The use of samples is carried out during small group trials, where the sample used is 6 (six) students from all populations in class X IPA 1 Surakarta Batik 2 High School 2017/2018 school year. This research is developing research or often referred to as Research and Development ( $\mathrm{R} \&$ D). Sugiyono (2009: 297) states that 
IJAMSR 2 (2) www.ijamsr.com CrossRef: https://doi.org/10.31426/ijamsr.2019.2.2.1213

\section{International Journal of Advanced Multidisciplinary Scientific Research (IJAMSR) ISSN:2581-4281}

development research (Research and Development) is a research method used to produce certain products, and test the effectiveness of these products. Development of I-Spring technology learning media includes five main stages, namely; (1) preliminary research, (2) design development, production, (4) product validation.

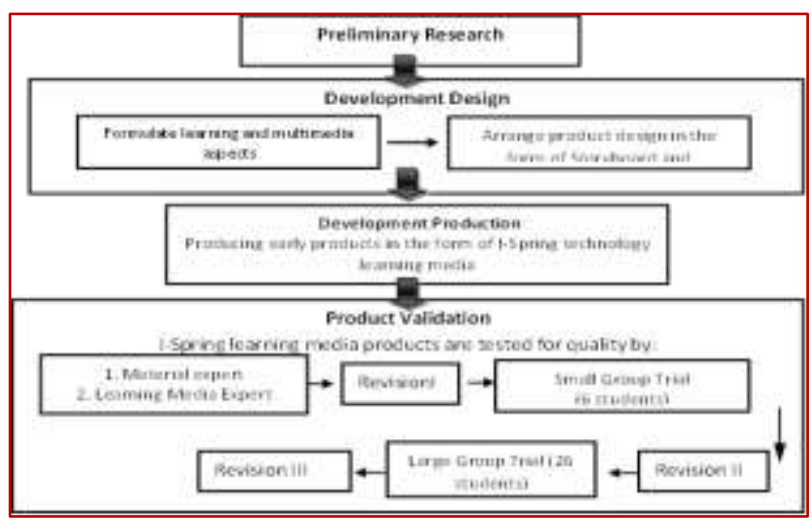

Figure 2. The procedure for developing ISpring technology learning media modified from the ADDIE (1996) and Borg and Gall (1998) models.

Preliminary research aims to collect data needed in research, such as; syllabus, lesson plan, student attendance, two-dimensional art material books, and others. The development, design formulates learning aspects and multimedia aspects that will be developed into a learning media product through storyboards and flow charts. The production stage is the stage of compiling and producing all aspects of multimedia (text, color, music, images, videos, animation) using a computer program that refers to the storyboard that has created. The last stage is product validation, the stage where the product in the form of two-dimensional art learning media produced, tested for its feasibility through several stages, namely; (1) expert test, (2) revision I, (3) small group trial, (4) revision II, (5) large group trial, (6) revision III.

\section{Results and Discussion}

\section{1) Preliminary Research}

The results of the cognitive, affective, and psychomotor pretest at the preliminary research stage are used to determine the condition of student learning achievement. The condition of learning achievement in two-dimensional art material in class X IPA 1 Surakarta Batik 2 High School as many as 26 students in this study showed $73 \%$ (19 students) did not meet the minimum completeness criteria, only $27 \%$ (7 students) were able to meet the minimum completeness criteria in the cognitive domain. These results are indicators that there are problems in learning two-dimensional art, especially in the cognitive aspects, namely the students' understanding of the material. The lack of quality of learning also reflected 
IJAMSR 2 (2) www.ijamsr.com CrossRef: https://doi.org/10.31426/ijamsr.2019.2.2.1213

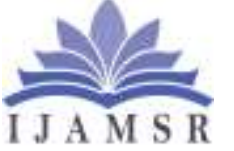

\section{International Journal of Advanced Multidisciplinary Scientific Research (IJAMSR) ISSN:2581-4281}

through the results of the effective assessment of students in the class, where $58 \%$ (15 students) have not achieved effective assessment in the good category (B), only $42 \%$ (11 students) have reached the good category. Both of these conditions certainly have an impingement on the psychomotor domain (skills) of students considering that the three aspects (cognitive, emotive, and psychomotor) are bound to each other. It is evident from the results obtained in the practice tests which showed that $62 \%$ (16 students) did not meet the minimum completeness criteria and only $38 \%$ (10 students) met the minimum completeness criteria.

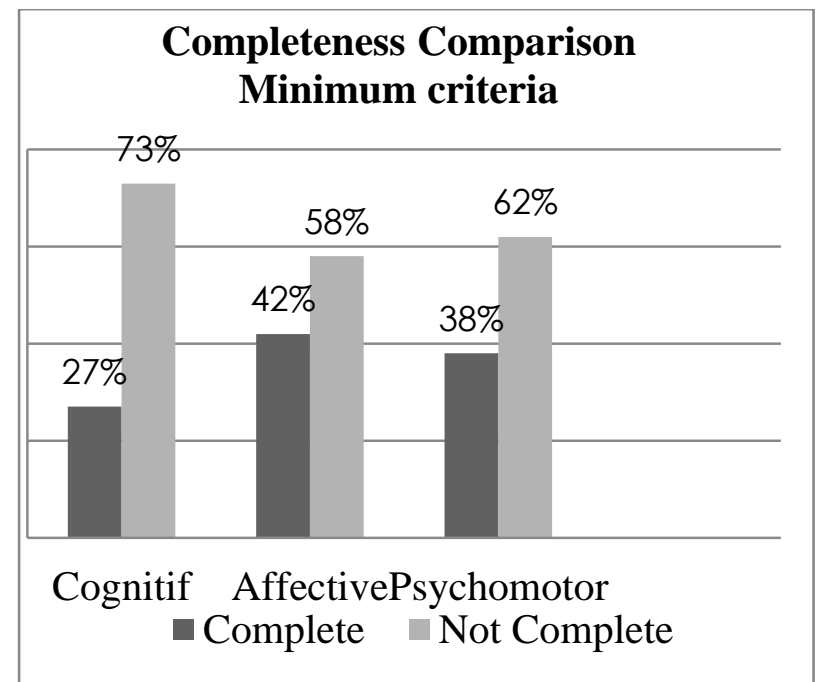

Graph 2. Percentage of comparison of Completeness Comparison Minimum criteria at pretest.

This condition is informed to all students to find out the difficulties and problems of students when the two-dimensional art learning activities take place. Based on the results of interviews with several students, it can conclude that students have difficulty understanding the material of two-dimensional art due to several factors, including: (1) cultural arts textbooks do not meet school needs, students take turns borrowing in libraries, (2) students feel bored with the situation learning too much lecture, (3) the time to study two-dimensional art material in the class is too short, (4) students have difficulty understanding test questions when dealing with questions that require examples of real images that match the material of twodimensional art.

Figure 1. I-Spring media program (Source: masternewmedia.org, 2017)

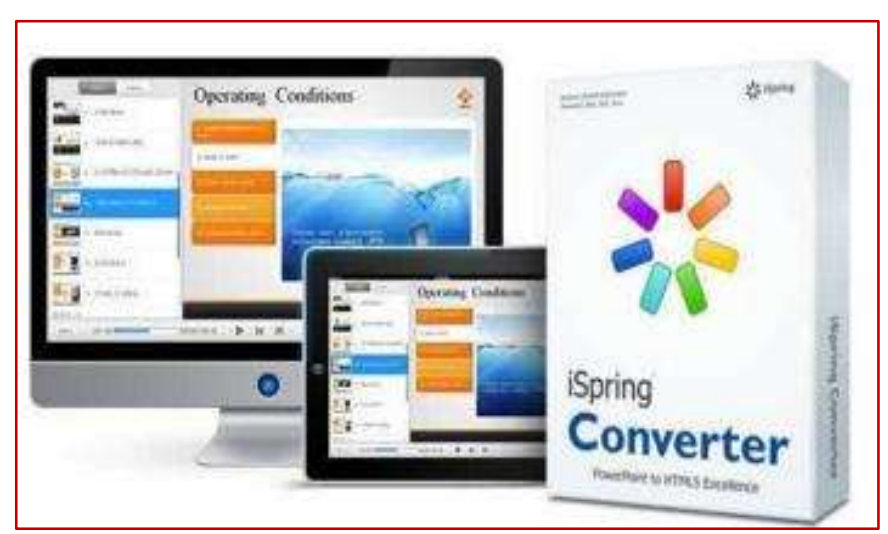

All data obtained from the results of initial observations are analyzed so that it can 


\section{International Journal of Advanced Multidisciplinary Scientific Research (IJAMSR) ISSN:2581-4281}

conclude that there is a need for research and development of learning media in twodimensional art material. Media development is needed to be an alternative solution for student learning that is attractive, effective, and efficient so that student achievement can maximize. Learning media developed in this study are computer-based with software called I-Spring.

\section{2) Development Design}

The stages of development, design include two subjects, namely the formulation of the learning slope and the multimedia aspects that arranged into a single unit in the I-Spring technology. The learning aspect can be arranged based on documents teaching the twodimensional art material such as; RPP and student handbooks, while multimedia aspects considered through data obtained from students and the theory of multimedia learning development.

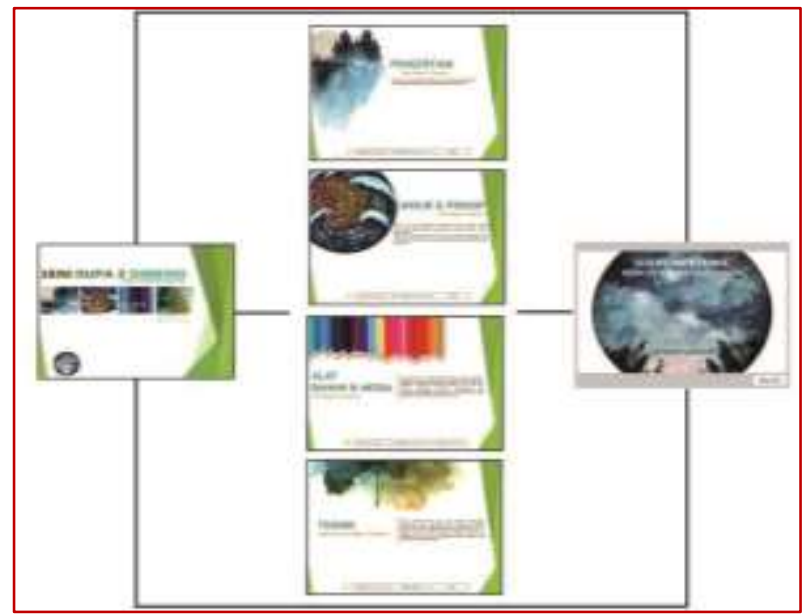

Figure 2. Story Board and Flow Chart on ISpring media.

Learning aspects include learning objectives, material, teaching methods, evaluation, and time allocation. Multimedia aspects include text, color, sound, video, image, animation. Compiling storyboards and flowcharts must be done before making the original product. Storyboards and flow charts are design drawings that explain the layout or sequence of a visual, audio, color, duration, and animation form.

\section{3) Production Phase}

The design drawing above is used as a guide when production is by the flow or stages of learning two-dimensional art material. The production process requires a combination of several programs such as; PowerPoint, ISpring, Scribe Video, Photoshop, CorelDraw, 
IJAMSR 2 (2) www.ijamsr.com CrossRef: https://doi.org/10.31426/ijamsr.2019.2.2.1213

\section{International Journal of Advanced Multidisciplinary Scientific Research (IJAMSR) ISSN:2581-4281}

and Cool EditPro. Computer equipment is very influential at the production stage, the higher the computer specifications, the easier it is to run the programs and the better quality visual results obtained. The most important factor is the knowledge of researchers in using mediamaking programs, learning, the more mastered the program, the better the product produced.

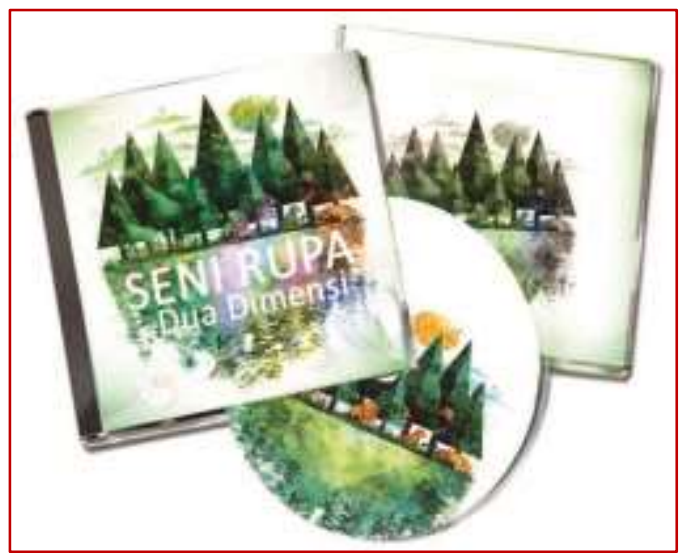

Figure 3. I-Spring two-dimensional art learning media products.

There are 3 (three) main stages of the production process of I-Spring technology learning media in two-dimensional art material, namely; (1) production of material, (2) editing, and (3) finishing. The first production stage is to make two-dimensional art materials based on the syllabus, learning implementation plans (RPP), and class X high school art and culture teaching books. There are several computer software that is needed to package the material in the form of an alternative file; PowerPoint programs, PhotoShop programs, and
VideoScribe programs. The editing process aims to package material into one menu to be effective and efficient. The next process is editing which includes several stages, namely; unifying book cover designs into the virtual book menu, integrating video into the presentation menu, creating a feedback menu in the form of a quiz and making the menu maker using hyperlinks. The finishing stage consists of 2 parts, namely: rendering and packaging. All multimedia parts that have edited and combined into one if the format is exe. So it becomes lighter to use.

\section{4) Product Validation}

I-Spring technology learning media products that have produced tested for quality through several stages; (1) expert tests by two respondents including material experts and multimedia learning experts using questionnaires, (2) revision I based on material expert suggestions and multimedia learning experts, (3) small group trials of 6 respondents who were sampled students using questionnaires, ( 4) revision II based on suggestions from the sample on small group trials, (5) large group trials followed by 26 students as respondents using the questionnaire as a test tool, (6) revision III based on suggestions from students in large group trials. 


\section{International Journal of Advanced Multidisciplinary Scientific Research (IJAMSR) ISSN:2581-4281}

The product validation test in the form of a closed questionnaire with the assessment criteria using the theory of multimedia learning development from Chee and Wong (2003: 11), states that to develop computer-based learning media must pay attention to learning aspects and multimedia aspects. Learning aspects include; learning objectives, material, methods, time allocation, and evaluation. Multimedia aspects include text, color, sound (audio), images (graphics), video, and animation (Tay Vaughan, 2006).

The rating scale used in the questionnaire is a Likert scale with four assessment criteria. The product must get a minimum quality rating of $64 \%$ with good criteria (feasible to use). The expert test and field test aims to obtain the percentage data on the quality/feasibility of ISpring technology learning media products from two-dimensional art material experts, multimedia learning experts, and students. The results of the expert assessment showed that the percentage of product, quality of learning media by $89 \%$ reviewed in terms of material and $93 \%$ in terms of multimedia learning, wherein the rating scale table the percentage of quality included the category "Very Good."

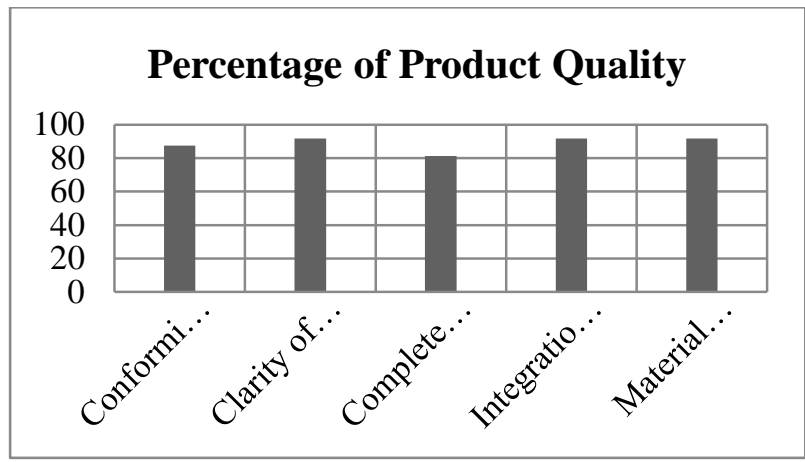

Graph 2. Percentage of validation of assessment of product quality of material experts.

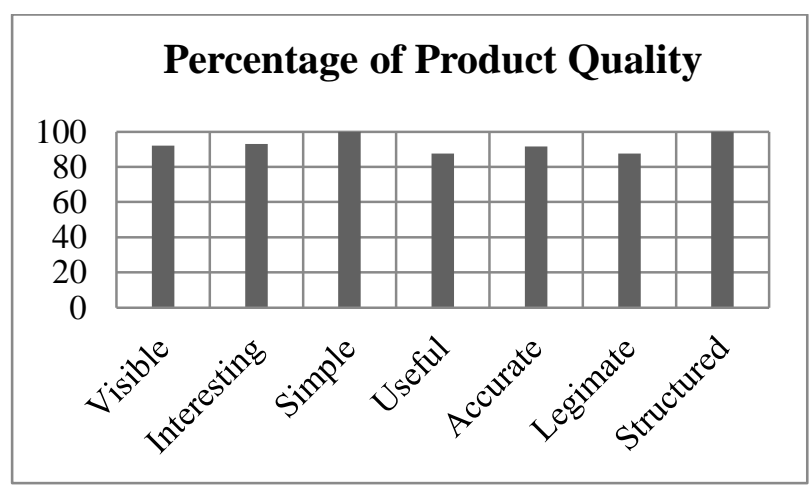

Graph 3. Percentage of validation assessment of product quality of multimedia experts.

Based on the graph above, it can be seen that the percentage of assessment of learning material and multimedia experts is "very good." Furthermore, the product can proceed to the small group trial validation stage through the process of revision I. The interview shows that Spring technology learning media, is an innovative breakthrough in the field of education and has an appeal to the multimedia aspect, to increase students' interest in learning two-dimensional art material. Revision I was 
IJAMSR 2 (2) www.ijamsr.com CrossRef: https://doi.org/10.31426/ijamsr.2019.2.2.1213

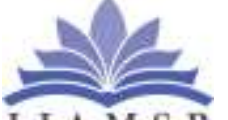

\section{International Journal of Advanced Multidisciplinary Scientific Research (IJAMSR) ISSN:2581-4281}

conducted to improve myself-Spring technology learning media products based on advice from material experts and multimedia learning experts. There are parts of I-Spring media products with two-dimensional art material that must be improved, namely the separation of material, materials, and media into three virtual books / digital books.

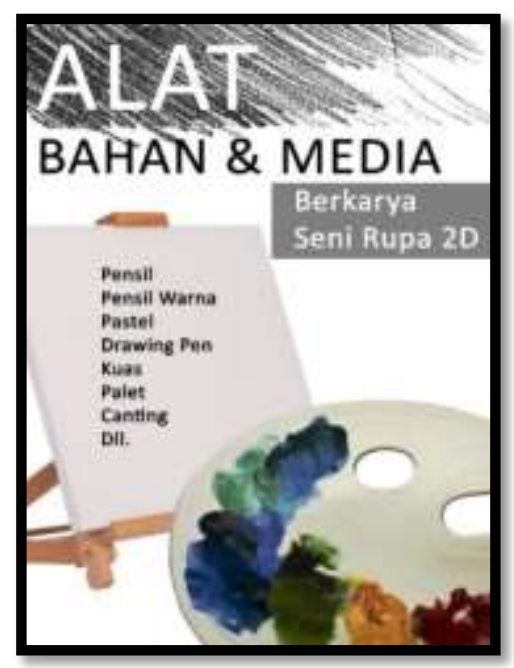

Figure 4. Preview of digital book cover before revision I

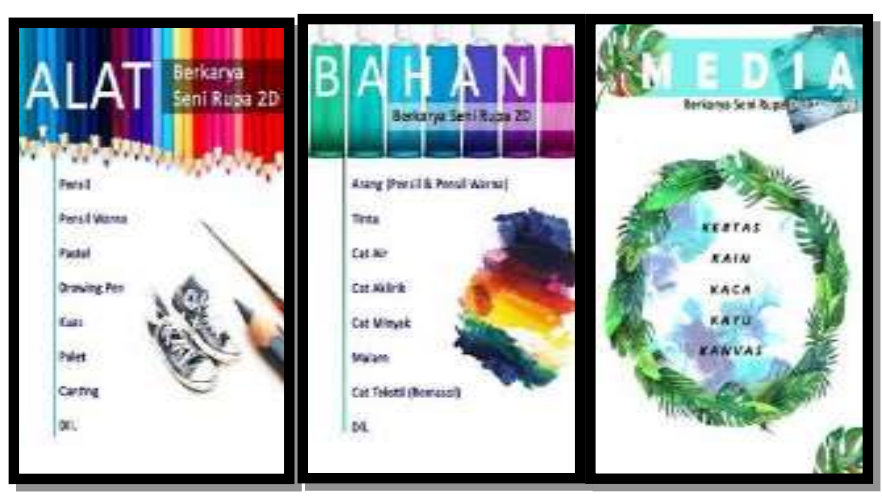

Figure 5. Preview of the cover of digital books after revised I
After the product undergoes revision I, then ISpring learning media products are tested in small groups consisting of 6 samples of students who become the respondents. The validation test instrument is a closed questionnaire with grading items using a Likert scale. Small group trials showed a percentage of the quality of I-Spring technology learning media products in two-dimensional fine art material at $88 \%$, wherein the rating scale table the percentage of quality included the category "Very Good." The interview results show that learning two-dimensional art material using ISpring technology learning media is very pleasant and the material is easy to understand. The advice given by some students is that there is a need to add the "Bottom Hyperlink" button on each presentation menu so that it is easy to see and easy to understand. These suggestions can be accepted, and improvements will make at the revision stage II.

Table 2. Results of product quality assessment in small group trials.

\begin{tabular}{|c|l|c|c|}
\hline No & Student & Nilai (\%) & Kategori \\
\hline 1 & Sample 1 & $92 \%$ & Very Good \\
\hline 2 & Sample 2 & $88 \%$ & Very Good \\
\hline 3 & Sample 3 & $86 \%$ & Very Good \\
\hline 4 & Sample 4 & $90 \%$ & Very Good \\
\hline 5 & Sample 5 & $91 \%$ & Very Good \\
\hline 6 & Sample 6 & $85 \%$ & Very Good \\
\hline \multicolumn{2}{|c|}{ Final Percentage } & $\mathbf{8 8 \%}$ & Very Good \\
\hline
\end{tabular}


IJAMSR 2 (2) www.ijamsr.com CrossRef: https://doi.org/10.31426/ijamsr.2019.2.2.1213

\begin{tabular}{c|c} 
International Journal of \\
I J A M S R
\end{tabular} Advanced Multidisciplinary Scientific Research (IJAMSR) ISSN:2581-4281

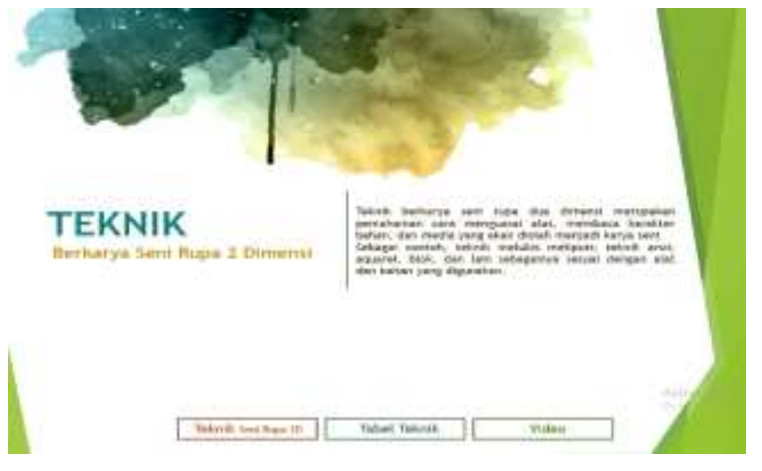

Figure 6. Preview revision II adds the Hyperlink Button marker.

The next stage is a large group trial, where ISpring technology learning media products in two-dimensional fine art materials were tested on all students in one class as many as 26 students who were respondents consisting of 10 male students and 16 female students. The results of large group trials show that the average value of the quality percentage of ISpring technology learning media products provided by students in large group trials is $90 \%$, wherein the rating scale table the percentage of quality includes the category "Very Good."

Table 3. Tabulation of results of product quality assessment in group trials.

\begin{tabular}{|c|c|c|c|c|c|c|c|c|c|c|c|c|c|}
\hline $\mathbf{R}$ & $\mathbf{1}$ & $\mathbf{2}$ & $\mathbf{3}$ & $\mathbf{4}$ & $\mathbf{5}$ & $\mathbf{6}$ & $\mathbf{7}$ & $\mathbf{8}$ & $\mathbf{9}$ & $\mathbf{1 0}$ & $\mathbf{1 1}$ & $\mathbf{1 2}$ & $\mathbf{1 3}$ \\
\hline $\boldsymbol{\%}$ & 91 & 86 & 94 & 86 & 96 & 93 & 90 & 85 & 90 & 94 & 87 & 94 & 85 \\
\hline $\mathbf{R}$ & 14 & 15 & 16 & 17 & 18 & 19 & 20 & 21 & 22 & 23 & 24 & 25 & 26 \\
\hline \% & 91 & 85 & 92 & 91 & 91 & 92 & 94 & 91 & 85 & 96 & 87 & 96 & 91 \\
\hline \multicolumn{10}{|c|}{ Average Score } & \multicolumn{1}{c|}{$\mathbf{9 0 \%}$} \\
\hline
\end{tabular}

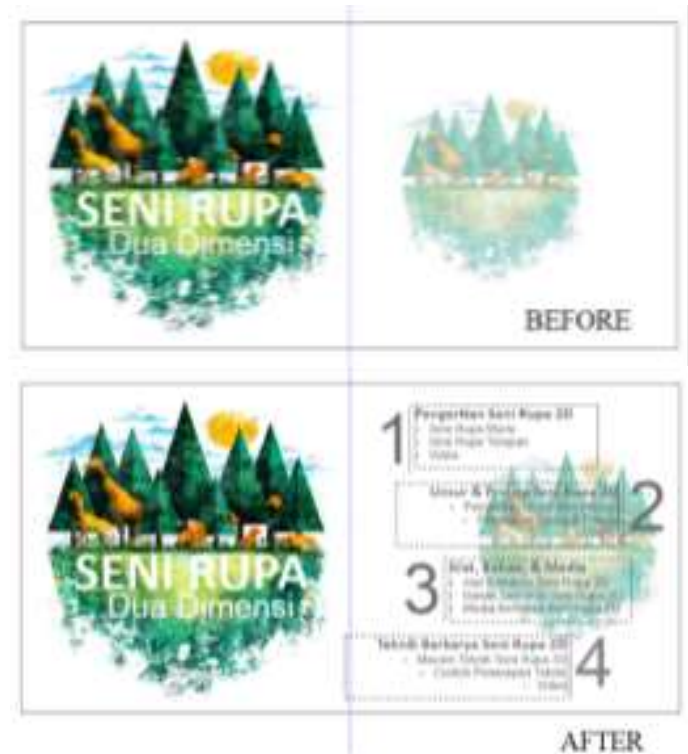

Figure 7. Preview revision III before and after repairing the packaging cover
The conclusion obtained from the large group field trials is that I-Spring technology learning media products are worthy of being used as an alternative to two-dimensional art learning media. The suggestions given by some students at the large group trial stage are the need for the addition of a table of contents, introduction text, and procedures for using media on the cover of I-Spring learning media products, so users know the content (material) and can use learning media products with correct 
procedure. These suggestions can be accepted, and improvements will make at the revision stage III.

I-Spring technology learning media products with two-dimensional art materials on average get an assessment percentage above $86 \%$ with the category "Very Good." Based on the stages that have been passed such as; product validation test from experts, revision I, small group quality test, revision II, large group quality test and revision III, then I-Spring technology learning all students can accept media products of two-dimensional art material and declared appropriate as an art learning twodimensional media appearance.

\section{Conclusion}

I-Spring technology learning media products are tools or facilities for learning twodimensional fine art materials that packaged through computer programs with an attractive and easy-to-use multimedia presentations. The most prominent advantage of I-Spring technology learning media products is having a Computer Based Test (CBT) based evaluation tool and having a multimedia format like a flash program that can attract students' attention. The development of I-Spring technology learning media needs to pay attention to two important aspects, namely the learning aspect and the multimedia aspect. Learning aspects that must be considered such as; learning objectives, material, time allocation, methods, and evaluation tools. While the multimedia aspects that need to consider include; text, image, color, audio, video, and animation. All of these aspects can package into one unit integrated into the subproducts of learning media so that learning activities will be of high quality and interesting because they presented with computer programs. For quality learning media products with I-Spring technology to be guaranteed, they need to test for their feasibility through several stages of product validation such as. The feasibility of the media measured through product validation must meet the minimum completeness criteria of $64 \%$ in the good category. The material expert test results were $89 \%$, the media expert test was $93 \%$, the smallest group test was $88 \%$, and the large group test was $90 \%$ with a very good category so that the product was declared feasible as a two-dimensional art learning medium.

\section{References}

1) Arsyad, Azhar. (2011). Media Pembelajaran. Jakarta: PT. Raja Grafindo Persada.

2) Daryanto. (2011). Media Pembelajaran. 
IJAMSR 2 (2) www.ijamsr.com CrossRef: https://doi.org/10.31426/ijamsr.2019.2.2.1213

Bandung: PT. Sarana Tutorial Nurani Sejahtera.

3) Hernawati Kuswari. 2010. Multimedia Pembelajaran Inovatif. Surabaya: Buku Kita.

4) Setyosari, Punaji. (2012). Metode Penelitian Pendidikan dan Pengembangan. Jakarta: Kencana.

5) Sugiyono. (2009). Metode Penelitian Kuantitatif, Kualitatif, dan R\&D. Bandung: ALFABETA.

6) Sulistyo, Edy Tri., Sunarmi., Widodo,
Jumiyanto. (2011). Media Pendidikan dan Pembelajaran di Kelas. Surakarta: UNS Press.

7) Taminudin, Muh (2010). Membuat Konten Pembelajaran dengan Power Point dan I-Spring. Jakarta: P4TK Matematika

8) Tay Vaughan. (2006). Multimedia: Making it Work. (Terjemahan Theresia Arie dan Agnes Heni). New York: Mc Graw HJill Companies, inc. 